\begin{abstract}
УДК 347.99 (470) (091)
ИВАНОВ Александр Александрович - доктор исторических наук, профессор кафедры отечественной истории исторического факультета Иркутского государственного университета (664003, Россия, г. Иркутск, ул. К. Маркса, 1; ottisk@irmail.ru)

КУРАС Татьяна Леонидовна - кандидат исторических наук, доцент кафедры судебного права Юридического института Иркутского государственного университета (664003, Россия, г. Иркутск, ул. К. Маркса, 1; tanya_kuras@mail.ru)

КУРАС Софья Леонидовна - кандидат исторических наук, доцент кафедры таможенного дела и правоведения Иркутского государственного университета путей сообщения (664074, Россия,

г. Иркутск, ул. Чернышевского, 15; kuras@list.ru)
\end{abstract}

\title{
ИСТОРИЯ СУДЕБНЫХ И ИНЫХ ПРАВООХРАНИТЕЛЬНЫХ ОРГАНОВ В ДОРЕВОЛЮЦИОННЫЙ ПЕРИОД: ПУТЕВОДИТЕЛЬ ПО ФОНДАМ ГОСУДАРСТВЕННОГО АРХИВА ИРКУТСКОЙ ОБЛАСТИ КАК ИСТОЧНИК ИЗУЧЕНИЯ
}

\begin{abstract}
Аннотация. Исследуется путеводитель 2017 г. по фондам Государственного архива Иркутской области как источник информации, его особенности по сравнению с ранее опубликованными. Издание является полным справочником, содержащим сведения о составе и содержании фондов архива. Его построение по отраслевому признаку, степени значимости, хронологии и алфавиту позволяет исследователям выявить необходимые фонды, описи и дела, изучить деятельность судебных органов, особенности каторги и ссылки, тюремного заключения осужденных преступников. Путеводитель открывает новые возможности в изучении указанных институтов.

Ключевые слова: Государственный архив, Иркутская область, документы и материалы, суд, пенитенциарная система, ссылка
\end{abstract}

$\Gamma$ осударственный архив Иркутской области (ГАИО) является одним из самых крупных региональных хранилищ документов дореволюционного периода, в т.ч. по истории судебной системы, каторги и ссылки. В нем сосредоточены 2600 фондов и более миллиона дел. Работа с таким объемом документов невозможна без профессионально составленного справочника. Для оптимизации работы исследователей в 2017 г. был издан путеводитель по фондам архива 1. В нем использованы современные достижения архивоведения [Иванов и др. 2019: 954]. Путеводитель 2017 г., в отличие от изданных ранее, является самым полным справочником о составе и содержании дореволюционных фондов ГАИО. ЕГо издание стало значимым событием, поскольку предыдущие выпуски существенно устарели.

Большим плюсом путеводителя является наличие содержательной исторической справки, предваряющей содержание фондов. Ведь изучение документов по теме судебной и штрафной системы в Сибири имеет свою специфику. Документы о деятельности судебных органов и управлении уголовной ссылкой

1 Путеводитель по фондам Государственного архива Иркутской области: в 2 ч. Ч. 1. Досоветский период (сост.: Ю.П. Колмаков, Е.А. Луговская, Н.В. Чичкова [отв. сост.], И.А. Чукавин, Н.В. Шашкова). Иркутск: Оттиск. 2017. 548 с. 
XIX - начала XX в. занимают важное место в фондах архива. Документы ГАИО, посвященные уголовной ссылке, весьма разнообразны. Это отчеты губернских ведомств о численности, движении ссыльных по региону, внутриведомственная переписка с прошениями осужденных и членов их семей. Описательная часть путеводителя к каждому фонду помогает определить источники хранящихся в описях дел. Особенностью документов по теме является их разрозненность по дореволюционным фондам. Поэтому детальное изложение в путеводителе исторической справки фонда и материалов к каждой описи помогает ускорить поиск информации. Проблемой, с которой сталкивались исследователи, изучая прошлые путеводители, было наличие в них информации только о политической ссылке. Новый же путеводитель разграничивает материалы о политической, административной и уголовной ссылке.

Значимыми являются фонды органов власти и управления. Одним из них является фонд 24 Главного управления Восточной Сибири. Он формировался с 1822 по 1887 г., содержит 28344 единиц хранения. Управление состояло из генерал-губернатора и Совета ГУВС с находящейся при них канцелярией. Значимость для Сибири вопросов ссылки подтверждается наличием в канцелярии ГУВС отделения, наблюдавшего за ссыльными и за государственными преступниками. По числу подведомственных управлению дел и разнообразию видов документов этот фонд - один из самых крупных в ГАИО среди дореволюционных. Во 2-й описи содержатся статистические сведения о численности ссыльных в Восточной Сибири за период с 1858 по 1883 г., межведомственная переписка о численности прибывающих в сибирский регион преступников и др. Опись 3 содержит сведения о числе лиц, отправленных в Восточную Сибирь на каторгу и ссылку за активную революционную деятельность. Здесь содержатся списки лиц, состоящих под надзором полиции. В статейных и алфавитных списках есть сведения и о политических, и об уголовных преступниках. Опись 10 содержит статистические сведения о численности ссыльных, сведения о строительстве, содержании тюрем в регионе. Опись 12 включает разные виды источников об уголовной ссылке: отчеты, обзоры о состоянии губернии, статейные, алфавитные списки ссыльных.

Фонд 25 Канцелярии Иркутского генерал-губернатора (с 1887 по 1917 г.) также содержит документы о штрафной колонизации в регионе. В фонде хранятся 44716 дел. Канцелярия была учреждена в 1887 г. на смену ликвидированному ГУВС для управления Енисейской, Иркутской губерниями и Якутской и Забайкальской областями. В 1-й, 2-й, 13-й описях содержатся прошения ссыльных по разным вопросам: о помиловании, разрешении вступить в брак, изменении места поселения, возвращении в Европейскую часть России и др. В описи 6 содержатся доклады тюремных отделений Енисейского, Иркутского губернских, Якутского областного управлений и тюремных комитетов. В делах имеются ведомости о содержании тюрем, этапных помещений, об устройстве поселенческих колоний, о численности, движении арестантов, числе их побегов. Опись включает сведения об увольнении от каторжных работ, об учреждении конвойных команд на трактах для сопровождения ссыльных. В описях 27 и 30 содержатся отчеты о деятельности Главного тюремного управления и тюремных комитетов.

Есть в ГАИО и фонды, содержащие сведения только о ссылке. Это фонд 34 - Иркутская губернская тюремная инспекция. Здесь хранятся ведомости о движении заключенных, журналы распределения ссыльных и др. Имеются и небольшие фонды $(226,227,228,454)$, посвященные пенитенциарной практике.

Значительный объем документов о политической ссылке, в частности, содер- 
жится в фонде 600 Иркутского губернского жандармского управления (18671917 гг.). Он обладает уникальными данными по истории личности ссыльных. Этот фонд включает 1312 единиц хранения, содержит много видов делопроизводственных источников: инструкции, распоряжения, письма по вопросам контроля за осужденными, о скорейшем поиске сбежавших с места отбывания наказания ссыльных. В фонде хранятся агентурные сведения о деятельности революционных организаций, имеются донесения и переписка о числе и занятиях ссыльнопоселенцев в Иркутской губернии, о благонадежности ссыльного элемента.

Путеводитель содержит обширную историческую справку об этапах развития судов и органов прокуратуры на территории Восточной Сибири. До проведения в Сибири Судебной реформы второй половины XIX в. на ее территории действовали разнородные суды. В 1823 г. вместо магистрата учрежден Иркутский городовой суд, существовавший до 1886 г. Он решал мелкие гражданские и уголовные дела купеческого и мещанского сословий. Информация размещена в фонде 241, содержащем одну опись, 695 дел. Городовые ратуши создавались в основном для рассмотрения уголовных и гражданских дел купцов и мещан. Сведения о работе Илимской городовой ратуши за 1778-1806 гг. содержатся в фонде 479, состоящем из одной описи, 29 единиц хранения. Работа Киренской городовой ратуши за 1800-1823 гг. освещена в фонде 36, состоящем из одной описи, 70 дел. К юрисдикции словесных судов относились торговые дела купцов и лиц других сословий. Так, информация об Иркутском словесном суде содержится в фонде 254, состоящем из одной описи, 44 единиц хранения за 1774-1891 гг.

Сиротский суд состоял из представителей купеческого, мещанского, ремесленного сословий. В обязанности входил учет вдов, ведение дел и попечение об осиротевших детях данных сословий. Этим судам посвящен фонд 280 , состоящий из трех описей 1-3, 203 единиц хранения за 1829-1920 гг., а также фонд Р-39, состоящий из одной описи, 6 дел за 1918-1919 гг. В Иркутске функционировало также Конкурсное управление по делам несостоятельных должников, рассматривавшее дела о торговой несостоятельности. Его деятельность освещается в фонде 229, содержащем 1 опись, 24 единицы хранения за 1876-1899 гг. Сведения о Киренской нижней расправе размещены в фонде 4, состоящем из одной описи, 75 дел за 1784-1797 гг. Суд рассматривал по первой инстанции уголовные и гражданские дела. С 1822 по 1897 г. он назывался Киренским окружным судом, решал дела городских и сельских жителей. Дела, посвященные его деятельности, размещены в фонде 7, состоящем из одной описи, 1108 единиц хранения. В нем содержатся, в частности, переписка о назначении и увольнении должностных лиц суда; о приходе и расходе денежных сумм; рапорты о решенных делах; уголовные дела, в т.ч. бежавших ссыльных.

На территории Иркутской губернии функционировала Иркутская палата уголовного суда и Иркутская палата суда и расправы (1782-1823 гг.). Сведения размещены в фонде 783 , состоящем из одной описи, 787 единиц хранения. В нем содержатся уголовные дела и дела ссыльных. В 1822 г. функции палаты переданы Иркутскому губернскому суду, функционировавшему до 1897 г. Информация о нем размещена в фонде 240 , состоящем из одной описи, 269 дел за 1846-1906 гг. Суд проверял акты окружных судов по гражданским и уголовным делам.

Институт мировых судей был создан при проведении в России судебной реформы 1864 г. для приближения суда к населению, рассмотрения незначительных гражданских и уголовных дел. В Сибири реформа была реализована 
в 1897 г. Сведения о деятельности отдельных мировых судей содержатся в двух фондах: 758 и 759.

Интерес для исследования представляют также фонды Иркутской палаты уголовного суда (фонд 783). В 1822 г. функции палаты были переданы Иркутскому губернскому суду, функционировавшему до 1897 г., документы о нем размещены в фонде 240. Суд проверял акты окружных судов по гражданским и уголовным делам. Здесь содержатся формулярные списки служащих суда, протоколы, журналы и т.д.

Работе Иркутского губернского прокурора (1797-1897 гг.) посвящен фонд 239: здесь имеются циркуляры по административно-судебным вопросам, материалы о подследственных, ссыльных и содержащихся под стражей, о преступлениях заключенных, личные дела чиновников судебного ведомства.

При проведении Судебной реформы в 1897 г. на территории Иркутской губернии был создан Иркутский окружной суд. Он рассматривал гражданские и уголовные дела, неподсудные мировым судьям, являлся апелляционной инстанцией для них. Дела суда содержатся в фонде 243, состоящем из 9 описей и 4841 единицы хранения за 1891-1920 гг. Ценными являются обзоры общественно-политических объединений, партий, движений, действовавших после революции 1905 г. Документы позволяют изучить события начала ХХ в., значимую роль в которых играли политические ссыльные.

Апелляционной инстанцией для окружных судов являлась Иркутская судебная палата, созданная в 1897 г. и выступавшая судом первой инстанции по делам о государственных преступлениях. Ей посвящен крупный фонд 246, содержащий 11 описей и 3482 дела за 1896-1919 гг. Министерство юстиции большое внимание уделяло вопросам финансирования судебных органов, т.к. проблемы содержания служащих новых судов за весь период их деятельности стояли весьма остро [Курас, Курас, Щербаков 2003: 76-83].

Институт стряпчих стал прообразом прокуратуры, на которую возлагались функции надзора за законностью и поддержанием порядка. Так, информация о работе киренского окружного стряпчего содержится в фонде 5 , состоящем из одной описи, 135 дел за 1784-1886 гг. Позднее были учреждены должности губернских прокуроров, существовавшие до проведения Судебной реформы. Деятельности Иркутского губернского прокурора (1797-1897 гг.) посвящен фонд 239, состоящий из описей 1 и 2, содержащий 94 единицы хранения. В фонде содержатся циркуляры по административно-судебным вопросам; материалы о подследственных, ссыльных и содержащихся под стражей; о преступлениях заключенных; личные дела чиновников судебного ведомства.

В 1897 г. при проведении Судебной реформы в Сибири вместо губернского прокурора была учреждена должность прокурора Иркутского окружного суда, который в соответствии с принципом централизации подчинялся прокурору Иркутской судебной палаты. Его деятельность освещена в фонде 242, состоящем из описей 1, 2, 3, 4, 1 ОЦ, содержащем 861 дело за 1890-1919 гг. Здесь размещен большой объем документов, связанных с функционированием прокуратуры.

Функционирование прокурора Иркутской судебной палаты в 1897-1920 гг. освешается в фонде 245 , содержашем описи $1,2,3,4,5,1$ ОЦ, состоящем из 4397 единиц хранения за 1883-1916 гг. Функции прокуратуры были чрезвычайно широки. В соответствии с законом прокуратура надзирала за соблюдением законодательства, фактически же власть возлагала на нее особую роль в поддержании обвинения и обеспечении вынесения жестких обвинительных приговоров в политических процессах. Она контролировала следствие и дознание, составляла обвинительные заключения, выполняла другие полно- 
мочия, подчиняясь напрямую министру юстиции и реализовывая политику самодержавия. В фонде 242, в частности, содержатся материалы проверки прокурором Иркутской судебной палаты деятельности должностных лиц прокуратуры Иркутского окружного суда. Определенный объем документов фонда 242 составляет переписка прокурора Иркутского окружного суда с председателем данного суда по важным судоустройственным и судопроизводственным вопросам. Так, в соответствии с законом, при невозможности обеспечить присутствие трех членов в заседании окружного суда для участия мог быть назначен один из местных судебных следователей, кроме тех, кто расследовал это дело. В практике Иркутского суда судебные следователи часто привлекались к участию в заседаниях, в результате они отвлекались от выполнения своих основных обязанностей. В предложении, направленном прокурором Иркутского окружного суда председателю суда, эта ситуация оценивалась отрицательно, прокурор просил привлекать судебных следователей к участию в заседаниях окружного суда в исключительных случаях ${ }^{1}$. Фонд 245 содержит ценные материалы по политической ссылке. Это представления служащих суда и прокуратуры по особо важным делам - терактам, побегам из тюрем и с этапов, забастовкам с выдвижением политических требований и т.д. В этих документах описаны основные действующие лица, партийная принадлежность революционеров, передан ход событий, процитированы листовки, требования, записки. Представления являются незаменимым источником, позволяющим исследовать значимые исторические события ${ }^{2}$.

Фонды ГАИО сохранили и уникальные свидетельства деятельности судов после свержения династии Романовых в 1917 г. Одной из проблем было сохранение материалов дел. Это было непростой задачей, т.к. новая власть старалась изъять дела в «революционных целях», используя материалы для поиска агентов жандармерии или героизации недалекого прошлого. Согласно циркуляру МВД от 6 апреля 1917 г. № 25241, изданного по соглашению с Военным министерством и Министерством юстиции, все архивы, дела и переписка жандармских управлений, розыскных пунктов и пр. в частях дел политического и общеуголовного характера по их разборке должны были быть переданы прокурорам окружных судов ${ }^{3}$.

Деятельность Иркутского военно-окружного суда отложилась в фонде 524, содержащем 2138 дел за 1889-1919 гг. Фонд содержит акты военного командования и Главного военного суда; журналы заседаний; уголовно-следственные дела и др. В пунктах, отдаленных от Иркутска, открывались временные военные суды. Такой суд был размещен в селе Александровском, однако фонд 577 содержит только 1 его дело. Временный военный суд был размещен и в Нижнеудинске, информация о нем содержится в фонде 509, состоящем из 3 дел.

Работа следователей также являлась значимой для проведения политики самодержавия в дореволюционный период. Так, в фонде 705, состоящем из 4 описей и 35 дел, освещается работа судебного следователя по особо важным делам Иркутского окружного суда. В нем содержатся, в частности, дела о революционной деятельности отдельных групп. Производство военного следователя 1-го участка Иркутского военно-окружного суда ограничивается делом за 1919 г., содержащимся в фонде Р-380. Работа следственных комиссий, созданных в 1918 г. для рассмотрения вопросов об обысках, выемках и внесу-

\footnotetext{
1 ГАИО. Ф. 242. ОП. 2. Д. 1. Л. 35-37.

2 ГАИО. Ф. 245. Оп. 1. Д. 535. Л. 116-126.

3 ГАИО. Ф. 245. ОП. 3. Д. 135. Л. 222-224, 321.
} 
дебных арестах, произведенных в период свержения советской власти, освещается в двух фондах. Иркутской губернской следственной комиссии посвящен фонд Р-163, содержащий 2 описи, 804 единицы хранения за 1918-1919 гг. Информация об Иркутской окружной следственной комиссии размещена в фонде Р-79, содержащем одну опись, 48 дел за 1918-1920 гг. В делах - списки заключенных и бывших красноармейцев, содержащихся в тюрьмах; документы по личному составу. Дело об Иркутской комиссии по ликвидации дел бывшего революционного трибунала и его следственных комиссий содержится в фонде P-2465.

Таким образом, документы ГАИО по вопросам работы судов, политической и уголовной ссылки относятся в основном к середине XIX - началу XX в. Здесь представлены законодательные акты и ведомственные материалы. Анализ документов позволяет изучить историю политической и уголовной ссылки дореволюционного периода. Профессионализм составителей путеводителя делает его издание крупным событием в научной жизни Восточно-Сибирского региона. Путеводитель является универсальным инструментом для поиска дел архива и выполняет задачу выявления, систематизации и описания исторических документов.

\section{Список литературы}

Иванов А.А., Ильина Е.В., Курас С.Л., Курас Т.Л. 2019. Издан новый путеводитель по фондам Государственного архива Иркутской области. - Вестник архивиста. № 3. С. 952-959.

Курас Л.В., Курас Т.Л., Щербаков Н.Н. 2003. История Иркутской судебной палаты (1897 - февраль 1917 гг.). Улан-Удэ: ИПК ВСГАКИ. 254 с.

IVANOV Aleksandr Aleksandrovich, Dr.Sci. (Hist.), Professor of the Chair of National History, Irkutsk State University (1 Karla Marksa St, Irkutsk, Russia,664003; ottisk@irmail.ru)

KURAS Tatyana Leonidovna, Cand.Sci. (Hist.), Associate Professor of the Chair of Justice, Law Institute, Irkutsk State University(1 Karla Marksa St, Irkutsk, Russia,664003; tanya_kuras@mail.ru)

KURAS Sofya Leonidovna, Cand.Sci. (Hist.), Associate Professor of the Chair of Customs Affairs and Jurisprudence, Irkutsk State Transport University (15 Chernyshevskogo St, Irkutsk, Russia, 664074; kuras@list.ru)

\section{THE GUIDE TO FUNDS OF THE STATE ARCHIVES OF THE IRKUTSK REGION AS A SOURCE FOR STUDYING THE HISTORY OF LAW ENFORCEMENT BODIES IN THE PRE-REVOLUTIONARY PERIOD}

\footnotetext{
Abstract. The authors study guidebook of 2017 on the funds of the State Archives of the Irkutsk Region as a source of information, show its features in comparison with previously published ones. The guidebook is the most complete guide to the composition and content of the SAIR funds. Its construction on the base of industry, degree of significance, chronology and alphabet allows researchers to identify the necessary funds, inventories and files, to study the activities of the judiciary, the features of hard labor and exile, the imprisonment of convicted criminals. The guide allows discovering new facets in the study of penitentiary institutions.
}

Keywords: state archive, Irkutsk Region, documents and materials, court, penitentiary system, link 